\title{
Impact of the method of managing opencast excavations by filling with mining waste on the quality of leachate entering the surface water
}

\author{
Sławomir Rzepecki \\ CTL Maczki-Bór S. A., Poland \\ Aneta Grodzicka \& Katarzyna Moraczewska-Majkut \\ Silesian University of Technology, Gliwice, Poland
}

SUMMARY: For years, environmental protection has been struggling with the problem of water contamination in Poland, especially salinity in surface water. The main source of water salinity in Poland is mining, so the problem of water salinity most affects the region of Silesia, which is characterized by a large number of hard coal mines and industrial plants. The hard coal mines located in Upper Silesia, during mining operations, pump large quantities of highly saline waters from the drainage of mine workings to the surface. Therefore, the problem of environmental protection is nowhere else on such a large scale. However, due to the fact that hard coal mines in our country constitute the main source of energy resources, solving the problem of saline water is difficult. The first part of the article presents the negative impact of salinity on water quality and resources in Poland and and it also indicates the economic effects associated with excessive salinity of rivers, which mainly include corrosive effects. The second part of the article will indicate the method of reclamation of the minefilling sand excavation, from which the leachate is discharged into surface water. As the reclamation takes place by filling the excavation with post-mining waste, there is a risk that saltwater may enter the surface water. This article also presents the example how to properly reclaim areas with post-mining waste and maintain good water status, to which leachate from the reclaimed area is discharged. The article specifies how much water from post-mining waste can be safely discharged into surface water, without creating the risk of excessive salinity. In the event of an imminent threat, there is an obligation to immediately take preventive measures, including immediate control, containment, removal or reduction of pollution or other harmful factors e.g. by controlling leachate effluent flows.

Keywords: opencast excavation, mining waste, surface water salinity

\section{INTRODUCTION}

Poland has relatively small water resources, which due to the geographical location, are supplemented by precipitation to a much lesser extent than in other European countries. In addition, high temperatures occurring in summer, lead to high evaporation losses. The greatest water reclamation capability is characterized by mountain areas, despite the fact that they do not have high retention capacities of the geological base (Chełmicki 2002).

The negative impact on water quality and resources related to human activities grew with the socio-economic development of the country. The strong development of industry caused an increasingly adverse impact on the water environment, including the salinity of waters. As 
of today, the question of the salinity of flowing waters is a significant problem in our country, whose solution has become a necessity. Undoubtedly, the greatest impact on the increase in the level of salinity of flowing water are adequate:

- discharges of underground water from hard coal mine,

- discharges of saline industrial sewage,

- municipal economy and agriculture.

Due to the occurrence of the largest hard coal mines in the Upper Silesian Industrial District, in connection with the sources of the two largest rivers in Poland - the Vistula and the Odra, the problem of salinity of waters flowing through mine water from mines occurs in Poland on a much larger scale than in other countries (Lipiński 1987).

The problem of water salinity has been known in Poland for many years. The first reports on this problem took place in the early 1960s. As previously mentioned, mining is the main source of water salinity in Poland. Upper coal mines located in Upper Silesia, in connection with mining activities, pump large quantities of highly saline waters from the drainage of mine workings to the surface. Additionally, an unfavourable aspect resulting from this fact is that hard coal mines are located in the upper section of the Vistula and Odra rivers, contributing to water pollution in other regions of the country (Miller 2004). Excessive salinity of waters causes degradation of biological life in rivers and the inability to use water resources for economic and industrial purposes. In addition, too high salt content can have a negative impact on the life and efficiency of hydrotechnical equipment, thus generating additional, high costs for overhauls and current repairs (Miller 2004).

\section{THE WATER SALINITY IN POLAND}

The water salinity in Poland is a very important problem in ecological and economic terms. The basic adverse effects of discharges, mainly through hard coal mine, excessively saline waters to rivers are (Grynkiewicz-Bylina \& Majewski 2000):

- degradation of the natural water environment,

- harmful and toxic effects on river flora and fauna,

- limiting or preventing the economic use of water resources,

- increase in costs related to saltwater treatment for municipal, industrial and agricultural purposes,

- corrosion of hydrotechnical equipment structures,

- the need to provide water for communal purposes from other regions of Poland.

The Silesian Voivodship, which is characterized by a large number of hard coal mines and industrial plants, is the most vulnerable region in Poland in the adverse impact of excessively saline flowing waters. Therefore, the problem of environmental protection is nowhere else on such a large scale (Nocon \& Nocon 2011). However, due to the fact that hard coal mines in our country constitute the main source of energy resources, for this reason solving the problem of saline water is difficult (Miller 2004). Currently, in Poland, hard coal is exploited from about 20 mines and they are the main source of water salinity.

Hard coal mining has been systematically declining - in the last 3 years it has not exceeded 67 million tonnes, as illustrated in Figure 1 (Państwowy Instytut Geologiczny 2018). However, it should be taken into account that every ton of extraction is associated with generated waste and mine waters.Source: Państwowy Instytut Geologiczny, 2018

Mines constitute the main source of excessive salinity of the Vistula and Odra rivers by pumping out and introducing huge amounts of chloride and sulphates charges into rivers and streams. The level of the components of the sum of chlorides and sulphates in the flowing waters of the Silesian agglomeration is notoriously exceeded. The vast majority of mines in mining plants discharges mine water directly to the receiver. Most, therefore, rivers are contaminated, to which the saline waters are directly introduced (Policht-Latawiec \& Kapica 2013). According to the statistical year of the Central Statistical Office, in 2016 the amount of 


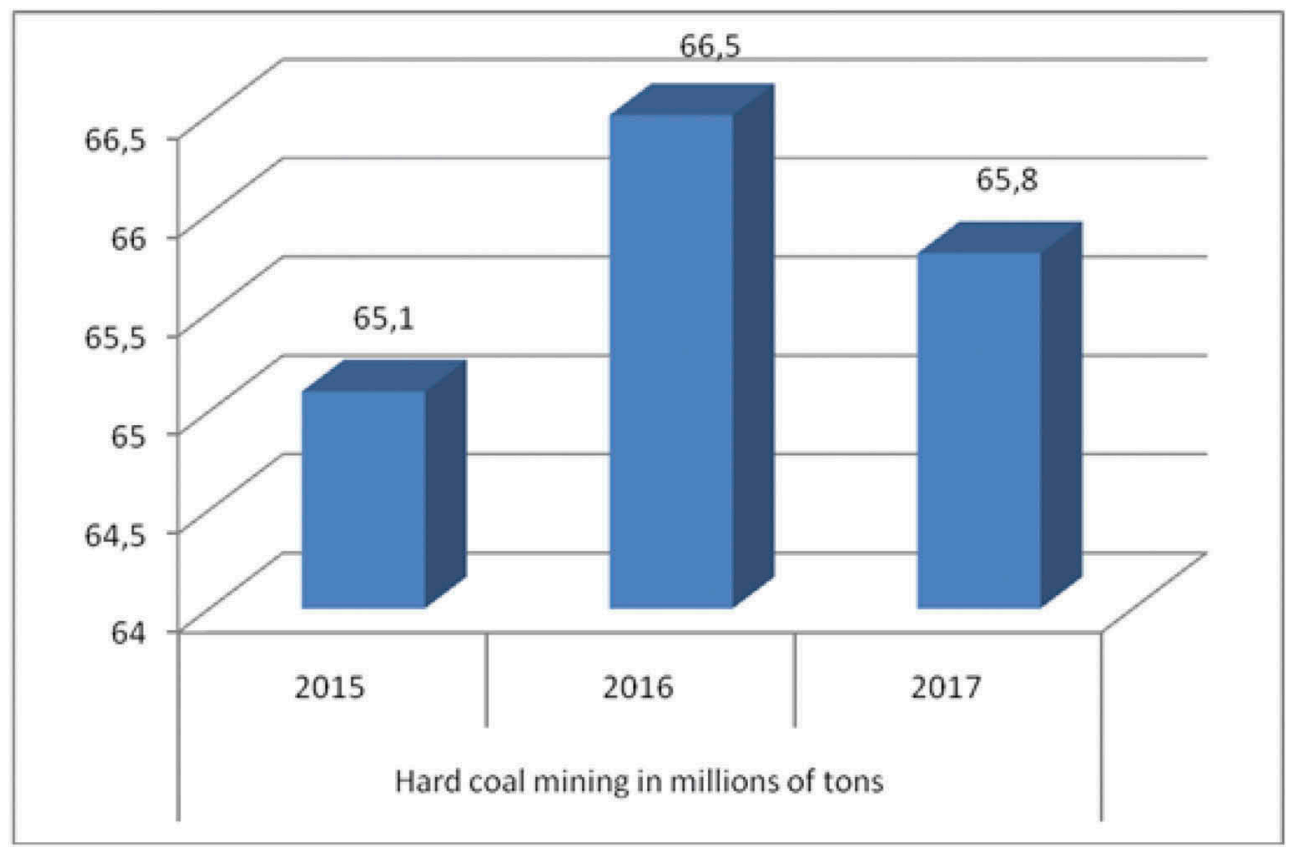

Figure 1. Hard coal mining in the period 2015-2017.

saline water discharged in the province Silesian for surface water is 112660 cubic decametres, and the amount of chloride and sulphate load in saline waters is 1598119 t/year, and discharged into inland waters is as high as 1228924 t/year, while only 369195 t/year was utilized (GUS 2017).

According to data from the WIOS in Katowice, in 2017, in the Silesia Voivodship, the majority of industrial waste $(96.9 \%$ of all waste generated in the voivodship) was generated by plants operating in the mining and quarrying (70.8\%). Among the generated industrial waste, waste from the rinsing and purification process of minerals predominated -20703 $900 \mathrm{Mg}(65.4 \%$ of generated waste), fly ash from coal - $1152100 \mathrm{Mg}(3.6 \%)$ and waste from flotation enrichment of coal - $1087600 \mathrm{Mg}(3.4 \%)$ (Inspection of Environmental Protection, Provincial Inspectorate of Environmental Protection in Katowice 2018). Among the waste generated as a result of the exploitation of underground hard coal deposits, two basic types of mining waste should be distinguished: mining and processing waste. Mining wastes come directly from mining preparatory works and are characterized by high variability of petrographic composition. Their grain composition ranges from 0-500 $\mathrm{mm}$. Processing wastes come from various processes of enriching raw material and are characterized by greater stability of the petrographic composition. Depending on the enrichment equipment used and the technology, the tailings are divided into: coarsegrained, fine-grained and flotation and other mud. The impact that mining waste may have on the aquatic environment is determined by many factors, including their physicochemical properties, hydrological, geological and climatic conditions prevailing at their place of use, as well as the construction of the deposit. During the deposit of waste they are exposed to atmospheric conditions and take part in the natural cycle of water circulation. They also depend on the methods of use and securing the excavation and on the ability of the environment to self-purify. In the case of utilization of post-mining waste excavations for reclamation, the potential environmental pollution is mainly related to the presence of chloride and iron sulphides in the material, which as a result of the development of oxidation processes are a source of sulphate and chloride ions (Kugiel \& Piekło 
2012). Taking into account the identification of the causes of the salinity of rivers throughout the country, it can be noticed that this problem is mainly of a local nature, mainly related to the region of the Upper Silesian Industrial District. The main source of saline water is the water discharged from the mines, but the article analyses the results of monitoring of surface waters discharged from the sites deposited post-mining waste.

\section{RECLAMATION OF THE OPENCAST EXCAVATIONS ON THE EXAMPLE OF MACZKI-BÓR}

\subsection{The method of reclamation of opencast excavations by filling with mining waste}

Mining activity of CTL Maczki-Bór S.A. in Sosnowiec is consists in the exploitation of sand deposits and the parallel implementation of the process of reclamation of post-mining excavations. The reclamation works are filled with mining waste from hard coal mines. They affect surface waters due to the location of backfilling sand deposits. The deposit lies in the fork of the Biała Przemsza River and its right-bank tributary - the Bobrek River. The deposit covers an area with a total area of over 558 ha, which has been divided into exploitation fields - the Bór Zachód field and the Bór Wschód field. Mine area dewatering is conducted in a gravitational manner with the participation of an extensive system of drainage ditches, which converge in the central part to the main channel. By this channel, the water is discharged into the sump of the main drainage, and from there to the Biała Przemsza River.

In the southern part of the Bór Zachód excavation, works related to the exploitation of sand are underway, and the remaining ones are subject to reclamation works aimed at leveling the basin of the excavation to the elevation of the surrounding area. In the area of about 200 ha, technical reclamation was completed. Land reclamation of the Bór Zachód field is intended for investments or as green areas. The remaining part of the degraded land surface exploitation of sand is covered by the reclamation process.

In the northern part of the Bór Wschód sand pit, the residual sand exploitation takes place. The area covered by the area of 220 hectares was covered by technical reclamation (from December 2004) aiming at the construction of a water reservoir with an area of 86.7 ha for recreational, retention or mixed purposes. Currently, the intended destination of the area is an industrial and investment objective with an accompanying green zone in the southern part.

Until October 2006, non-hazardous waste was delivered to the area of sandblast excavations: post-mining, energy (used for fire prevention) and neutral. Only mining waste from coal pre-treatment and enrichment as well as construction debris waste has been used for reclamation of sandblasting pits since October 2006. All used waste is non-hazardous waste. Before accepting waste for use in the reclamation of CTL Maczki-Bór S.A. requires suppliers to provide information on their physicochemical properties.

During filling the basin of the Bór Zachód excavation, dozens of hard coal mines were suppliers of waste including hard coal mines:

- Zagłębie coal mines: Niwka Modrzewów Sosnowiec, Jan Kanty Jaworzno and Siersza;

- Katowice: Kleofas, Wujek, Staszic, Wesoła;

- Rybnik coal mines: Śląsk, Polska Wirek, Zabrze Bielszowice, Pokój;

- Vistula coal mines: Ziemowit, Piast, Czeczot, Janina,

- mines from the area of Ruda Śląska: Silesia, Poland, Wirek, Zabrze, Bielszowice, Pokój.

In the second stage of operation, waste from the mines was used to fill the excavation:

- Katowicki Holding Węglowy: Staszic, Wujek, Wesoła, Murcki,

- Kompania Węglowa: Piast, Ziemowit,

- Południowy Koncern Energetyczny: Janina, Sobieski.

These wastes are gangue rocks composed of clays and siltstones, and in a small part sandstones with overgrown coal. In addition, the qualified "Haldex" aggregate from the mining 
waste decarburization processes carried out at the Extraction Waste Treatment Plant (ZPOW), located at CTL Maczki-Bór SA, is also used.

\subsection{Impact of leachate from the excavation fill on surface water}

The Biała Przemsza River flows along the southern border of the Mines Mining Plant CTL Maczki-Bór S.A. in the latitudinal direction from east to west. It is a tributary of the Czarna Przemsza, with which it connects in the "Jęzor" district on the site of the former NiwkaModrzejów mine. From this point the river takes the name of Przemsza and flows to the south-east along the border of the "Jaworzno" OG. Drainage of headings CTL Maczki-Bór S. A. is guided by a system of ditches, converging in the middle part to the east-west main duct. With this channel, the water flowing into the outcrop is discharged to the area of BórZachód, and from there pumped to the Biała Przemsza River. The flow of water at the mouth of the channel to the river varies at the level of $0.38 \mathrm{~m}^{3} / \mathrm{s}$.

In order to demonstrate the impact of water discharged from the "Maczki - Bór" CTL on the salinity of the Biała Przemsza River, the results of monitoring studies carried out in 5 research periods presented. The research included water sampling at the place of discharge from the grit chambers to Biała Przemsza and two points located about $400 \mathrm{~m}$ above and below the discharge from the CTL "Maczki - Bór" to Biała Przemsza. Table 1 presents the results of analyses.

With regard to limit values of indicators specified in the ordinance of the Minister of the Environment regarding the method of classifying the status of uniform surface water bodies and environmental quality standards for priority substances (defined in the Journal of Law from 2014 item 1482), in the drainage waters of the "Bór-Zachód" field, increased conductivity and suspension were observed, which was influenced by concentrations of chlorides and sulphates in the discharged water.

In terms of sulphates, the water discharged from the grit chamber to the river contributed meaningless changes in sulfate concentrations after the discharge. In 1 period, they indicated even smaller values than before the discharge, which resulted in an additional improvement in water quality. In terms of chlorides, water discharged from the grit chamber into the river also contributed small increase in chloride concentrations, without affecting the change in the water quality class. The water of the river, both before and after discharge, usually belong to the waters below class II. Only two single measurements in 2 and 3 periods indicated the quality of first class water before discharge, and after discharge these waters were of a quality below class II, so the discharge from the grit chamber deteriorated water quality.

It is important that the pollution load does not limit the process of self-purification of surface water, as the receiver is the next stage in the treatment of polluted waters. Most models used to analyze the impact of pollutant discharge on water quality assume complete mixing at or near the discharge point. This mixing process is rare, however, for the purposes of describing the state of the river, the assumption of complete mixing is sufficient. The speed of mixing wastewater with river water depends on its amount and the size and speed of water flow, as well as the width and depth of the watercourse. It is also very important to maintain oxygen conditions throughout the river, appropriate for living organisms receiving the receiver and an efficient self-purification process. Therefore, it is important not only to monitor the concentration of pollutants in treated wastewater, but also to determine their impact on the receiving water. In the event that grit chamber outlet worsen the quality of the receiving waters and the results indicate a reduction in water class (as in periods 2 and 3), it should be recommended to reduce the leachate flow. Using the formula for concentration of pollutants in the river after entering the outlet assuming complete mixing:

$$
C=\frac{Q_{r} C_{r}+q_{O} C_{O}}{Q_{r} q_{O}}
$$


Table 1. Results of analyses water above and below the grit chambers and discharged from the grit chambers to Biała Przemsza.

\begin{tabular}{|c|c|c|c|c|c|c|}
\hline $\begin{array}{l}\text { Analyses } \\
\text { period }\end{array}$ & Place of sampling & $\begin{array}{l}\text { Total } \\
\text { suspension } \\
\mathrm{mg} / 1\end{array}$ & $\begin{array}{l}\text { Chloride } \\
\mathrm{mg} / \mathrm{l}\end{array}$ & $\begin{array}{l}\text { Sulphate } \\
\mathrm{mg} / \mathrm{l}\end{array}$ & $\mathrm{pH}$ & $\begin{array}{l}\text { Electric con- } \\
\text { ductivity } \mu \mathrm{S} / \mathrm{cm}\end{array}$ \\
\hline \multirow[t]{6}{*}{1} & \multirow{6}{*}{$\begin{array}{l}\text { Biała Przemsza above the grit } \\
\text { chamber } \\
\text { Water discharge from the grit } \\
\text { chamber to Biała Przemsza } \\
\text { Biała Przemsza below the grit } \\
\text { chamber }\end{array}$} & 77 & 44 & 183 & 8,3 & 580 \\
\hline & & 8,2 & 46 & 233 & 7,4 & 792 \\
\hline & & 23 & 227 & 263 & 8,1 & 1641 \\
\hline & & 6 & 310 & 184 & 7,6 & 1943 \\
\hline & & 48 & 43 & 167 & 8,3 & 605 \\
\hline & & 8,4 & 72 & 202 & 7,7 & 896 \\
\hline \multirow[t]{6}{*}{2} & \multirow{2}{*}{$\begin{array}{l}\text { Biała Przemsza above the grit } \\
\text { chamber }\end{array}$} & 86 & 19 & 50 & 7,6 & 282 \\
\hline & & 9,2 & 43 & 199 & 8,1 & 737 \\
\hline & \multirow{2}{*}{$\begin{array}{l}\text { Water discharge from the grit } \\
\text { chamber to Biała Przemsza }\end{array}$} & 20,4 & 261 & 219 & 7,6 & 1920 \\
\hline & & 5,6 & 231 & 266 & $\begin{array}{l}7,7- \\
8,3\end{array}$ & 1963 \\
\hline & \multirow{2}{*}{$\begin{array}{l}\text { Biała Przemsza below the grit } \\
\text { chamber }\end{array}$} & 108 & 28 & 58,8 & 7,6 & 283 \\
\hline & & 9,6 & 69 & 221 & 8,1 & 849 \\
\hline \multirow[t]{6}{*}{3} & \multirow{2}{*}{$\begin{array}{l}\text { Biała Przemsza above the grit } \\
\text { chamber }\end{array}$} & 28,5 & 43 & 181 & 7,9 & 790 \\
\hline & & 19,4 & 39 & 178 & 8,0 & 772 \\
\hline & \multirow{2}{*}{$\begin{array}{l}\text { Water discharge from the grit } \\
\text { chamber to Biała Przemsza }\end{array}$} & 24,8 & 214 & 270 & $\begin{array}{l}\text { no } \\
\text { data }\end{array}$ & 1530 \\
\hline & & 7,8 & 300 & 180 & $\begin{array}{l}\text { no } \\
\text { data }\end{array}$ & 1910 \\
\hline & \multirow{2}{*}{$\begin{array}{l}\text { Biała Przemsza below the grit } \\
\text { chamber }\end{array}$} & 38,5 & 65 & 209 & 7,8 & 890 \\
\hline & & 30,3 & 72 & 230 & 8,0 & 860 \\
\hline \multirow[t]{6}{*}{4} & \multirow{2}{*}{$\begin{array}{l}\text { Biała Przemsza above the grit } \\
\text { chamber }\end{array}$} & 36,5 & 52 & 200 & 7,9 & 797 \\
\hline & & 5 & 52 & 226 & 7,8 & 855 \\
\hline & \multirow{2}{*}{$\begin{array}{l}\text { Water discharge from the grit } \\
\text { chamber to Biała Przemsza }\end{array}$} & 6 & 262 & 228 & $\begin{array}{l}\text { no } \\
\text { data }\end{array}$ & 1510 \\
\hline & & 4 & 240 & 245 & $\begin{array}{l}\text { no } \\
\text { data }\end{array}$ & 1710 \\
\hline & \multirow{2}{*}{$\begin{array}{l}\text { Biała Przemsza below the grit } \\
\text { chamber }\end{array}$} & 28 & 41 & 201 & 7,8 & 884 \\
\hline & & 15 & 85 & 234 & 7,6 & 820 \\
\hline \multirow[t]{6}{*}{5} & \multirow{2}{*}{$\begin{array}{l}\text { Biała Przemsza above the grit } \\
\text { chamber }\end{array}$} & 27 & 40 & 213 & 7,5 & 750 \\
\hline & & 12,4 & 40 & 227 & 7,9 & 870 \\
\hline & \multirow{2}{*}{$\begin{array}{l}\text { Water discharge from the grit } \\
\text { chamber to Biała Przemsza }\end{array}$} & 8 & 277 & 222 & $\begin{array}{l}\text { no } \\
\text { data }\end{array}$ & 1670 \\
\hline & & 7,2 & 220 & 320 & $\begin{array}{l}\text { no } \\
\text { data }\end{array}$ & 1620 \\
\hline & \multirow{2}{*}{$\begin{array}{l}\text { Biała Przemsza below the grit } \\
\text { chamber }\end{array}$} & 28 & 69 & 227 & 7,8 & 900 \\
\hline & & 14 & 56 & 227 & 8,0 & 968 \\
\hline
\end{tabular}

Source: CTL Maczki-Bór S.A..

which: $\mathrm{Q}_{\mathrm{r}}$ and $\mathrm{qo}_{\mathrm{o}}$ - river and outlet water flow $\left[\mathrm{m}^{3} \cdot \mathrm{s}^{-1}\right] \mathrm{C}_{\mathrm{r}}$ and $\mathrm{C}_{\mathrm{O}}$ - concentration of a given component in the river water above the outlet and in the outlet water $\left[\mathrm{g} \cdot \mathrm{m}^{-3}\right]$,

it is possible calculate the appropriate amount of leachate discharged from the grit chamber:

$$
q_{O}=\frac{C_{r}}{C-\frac{C_{O}}{Q_{r}}}
$$

Although the water discharged from the excavation drainage system meets the requirements of the water permit, it seems reasonable to increase the protection of the receiving waters, i.e. the river, by using an intelligent water drainage system. 
Table 2 presents the results of physicochemical analyzes of water discharged to the Biała Przemsza in relation to the permissible values of pollutants contained in the Regulation of the Minister of Environment of November 7, 2019 on conditions to be met when introducing sewage into waters or to land, and on substances particularly harmful to the aquatic environment (Journal of Laws of 2019, item 2149). Analyses included determination of reaction, dry residue, total suspended solids, conductivity, chlorides, sulphates, bicarbonates, calcium, magnesium, general hardness (total calcium and magnesium), sodium, potassium, general iron, manganese, zinc and lead.

The quality of wastewater discharged from the grit chamber to Biała Przemsza, in terms of all analyzed indicators, meets the requirements of the Regulation of the Minister of the Environment of November 7, 2019, on conditions to be met when introducing wastewater into waters or soil, and on particularly harmful substances for the water environment (Journal of Laws of 2019, item 1311), for treated industrial wastewater. In this case, there are no indications to take any additional action.

Table 2. Results of analyses physicochemical parameters in water at the outlet of the grit chamber and limit values in treated industrial wastewater (according Journal of Laws of 2019, item 1311).

\begin{tabular}{|c|c|c|c|c|c|c|}
\hline Parameters [unit] & Period 1 & Period 2 & Period 3 & Period 4 & Period 5 & $\begin{array}{l}\text { The highest } \\
\text { permissible } \\
\text { values of } \\
\text { pollution }\end{array}$ \\
\hline \multirow{2}{*}{$\mathrm{pH}$} & 8,1 & 7,6 & No data & No data & No data & \multirow{2}{*}{$6,5-9,0$} \\
\hline & 7,6 & $7,7-8,3$ & No data & No data & No data & \\
\hline \multirow{2}{*}{ Electric conductivity $[\mu \mathrm{S} / \mathrm{cm}]$} & 1641 & 1920 & 1530 & 1510 & 1670 & \multirow{2}{*}{ No data } \\
\hline & 1943 & 1963 & 1910 & 1460 & 1620 & \\
\hline \multirow{2}{*}{ Dry residue [mg/l] } & 1020 & 1408 & 1384 & 1200 & 1500 & \multirow{2}{*}{ No data } \\
\hline & 1005 & 1332 & 1580 & 1372 & 1280 & \\
\hline \multirow{2}{*}{$\mathrm{COD}-\mathrm{Cr}\left[\mathrm{mgO}_{2} / \mathrm{l}\right]$} & 27 & 57 & 32 & 32 & 18 & \multirow{2}{*}{125} \\
\hline & 27 & $<25$ & 38 & 24 & 20 & \\
\hline \multirow{2}{*}{ BOD-5 $\left[\mathrm{mgO}_{2} / 1\right]$} & 6,78 & 9,5 & 8 & 6,4 & 4,5 & \multirow{2}{*}{25} \\
\hline & 4,5 & 3 & 12,6 & 4,8 & 5,8 & \\
\hline \multirow{2}{*}{ Ammonium nitrogen $\left[\mathrm{mgN}-\mathrm{NH}_{4} / \mathrm{l}\right]$} & 0,24 & 0,4 & 0,46 & 1,0 & 1,06 & \multirow{2}{*}{10} \\
\hline & 0,21 & 0,84 & 0,7 & 1,09 & 2,61 & \\
\hline \multirow{2}{*}{ Nitrate nitrogen $\left[\mathrm{mgN}-\mathrm{NO}_{3} / \mathrm{l}\right]$} & 0,34 & 0,58 & 0,45 & 0,76 & 0,25 & \multirow{2}{*}{30} \\
\hline & 0,44 & 0,43 & 0,28 & 0,14 & 0,36 & \\
\hline \multirow{2}{*}{ Total nitrogen $\mathrm{N}_{\text {total }}[\mathrm{mgN} / \mathrm{l}]$} & 1,6 & 3,6 & 2,06 & 2,6 & 4,96 & \multirow{2}{*}{30} \\
\hline & 4,2 & 21 & 3,9 & 8,8 & 4,62 & \\
\hline \multirow{2}{*}{ Total phosphorus [mgP/l] } & 0,14 & 0,41 & 0,13 & $<0,10$ & $<0,10$ & \multirow{2}{*}{2} \\
\hline & 0,35 & 0,06 & $<0,10$ & $<0,10$ & $<0,10$ & \\
\hline \multirow{2}{*}{ Chloride $[\mathrm{mgCl} / \mathrm{l}]$} & 227 & 261 & 214 & 262 & 277 & \multirow{2}{*}{1000} \\
\hline & 310 & 231 & 300 & 218 & 220 & \\
\hline \multirow{2}{*}{ Sulphate $\left[\mathrm{mgSO}_{4} / \mathrm{l}\right]$} & 263 & 219 & 270 & 228 & 222 & \multirow{2}{*}{500} \\
\hline & 184 & 266 & 180 & 266 & 320 & \\
\hline \multirow{2}{*}{ Volatile phenols [mg/l] } & 0,01 & $<0,002$ & $<0,002$ & 0,008 & $<0,002$ & \multirow{2}{*}{0,1} \\
\hline & $<0,002$ & $<0,002$ & $<0,002$ & $<0,002$ & 0,011 & \\
\hline \multirow{3}{*}{ Fluoride [mg/l] } & $<0,10$ & $<0,10$ & $<0,10$ & $<0,10$ & $<0,10$ & \multirow{2}{*}{25} \\
\hline & 7,6 & $<0,10$ & $<0,10$ & $<0,10$ & $<0,10$ & \\
\hline & 271 & 268 & 311 & 305 & 342 & \multirow{3}{*}{ No data } \\
\hline \multirow[t]{2}{*}{ Bicarbonates $\left[\mathrm{mgHCO}_{3} / 1\right]$} & $<0,10$ & 323 & 280 & 366 & 336 & \\
\hline & 317 & 346 & 337 & 492 & 407 & \\
\hline \multirow{2}{*}{ Calcium [mgCa/l] } & 144 & 148 & 148 & 146 & 70 & \\
\hline & 486 & 85 & 88 & 137 & 116 & No data \\
\hline Magnesium [moMg/ll & 33,8 & 44,1 & 43,3 & 39,8 & 28 & Nodata \\
\hline Magnesıum [mgMg/I] & 138 & 32,5 & 28,6 & 36,3 & 28,6 & No data \\
\hline
\end{tabular}




\begin{tabular}{|c|c|c|c|c|c|c|}
\hline Parameters [unit] & Period 1 & Period 2 & Period 3 & Period 4 & Period 5 & $\begin{array}{l}\text { The highest } \\
\text { permissible } \\
\text { values of } \\
\text { pollution }\end{array}$ \\
\hline \multirow[t]{2}{*}{ Sodium [mgNa/l] } & 179 & 199 & 222 & 202 & 220 & \multirow{2}{*}{800} \\
\hline & 34,5 & 129 & 180 & 188 & 140 & \\
\hline \multirow{2}{*}{ Potassium [mgK/l] } & 8,86 & 11,2 & 10,4 & 15,2 & 5,78 & \multirow{2}{*}{80} \\
\hline & 168 & 7,4 & 9,2 & 12,3 & 16 & \\
\hline \multirow{2}{*}{ Total iron $[\mathrm{mgFe} / \mathrm{l}]$} & 0,25 & $<0,010$ & $<0,010$ & 0,77 & 0,18 & \multirow{2}{*}{10} \\
\hline & 7,82 & $<0,010$ & $<0,010$ & 0,85 & 0,026 & \\
\hline \multirow{2}{*}{ Manganese [mgMn/l] } & 0,7 & 0,57 & 0,43 & 0,71 & 0,28 & \multirow{2}{*}{ No data } \\
\hline & 0,58 & 0,13 & $<0,005$ & 0,64 & 0,46 & \\
\hline \multirow{2}{*}{$\operatorname{Bar}[\mathrm{mgBa} / \mathrm{l}]$} & 0,14 & 0,12 & 0,11 & 0,13 & 0,05 & \multirow{2}{*}{2,0} \\
\hline & $<0,010$ & 0,1 & 0,06 & 0,12 & 0,18 & \\
\hline \multirow{2}{*}{ Total chrome [mgCr/l] } & $<0,005$ & $<0,005$ & $<0,005$ & $<0,005$ & $<0,005$ & \multirow{2}{*}{0,5} \\
\hline & $<0,005$ & $<0,005$ & $<0,005$ & $<0,005$ & $<0,005$ & \\
\hline \multirow{2}{*}{ Zinc $[\mathrm{mgZn} / \mathrm{l}]$} & 0,059 & $<0,020$ & $<0,020$ & $<0,02$ & $<0,020$ & \multirow{2}{*}{2,0} \\
\hline & 0,024 & $<0,020$ & $<0,020$ & $<0,020$ & $<0,020$ & \\
\hline \multirow{2}{*}{ Cadmium [mgCd/l] } & $<0,0010$ & $<0,001$ & $<0,0010$ & $<0,0010$ & $<0,001$ & \multirow{2}{*}{0,4} \\
\hline & $<0,001$ & $<0,001$ & $<0,001$ & $<0,001$ & $<0,0010$ & \\
\hline \multirow{2}{*}{ Copper $[\mathrm{mgCu} / \mathrm{l}]$} & $<0,005$ & $<0,005$ & $<0,005$ & $<0,005$ & 0,0078 & \multirow{2}{*}{0,5} \\
\hline & 0,018 & $<0,005$ & $<0,005$ & $<0,005$ & $<0,005$ & \\
\hline \multirow{2}{*}{ Lead $[\mathrm{mgPb} / \mathrm{l}]$} & $<0,010$ & $<0,010$ & $<0,010$ & $<0,010$ & $<0,010$ & \multirow{2}{*}{0,5} \\
\hline & $<0,010$ & $<0,010$ & $<0,0020$ & $<0,010$ & $<0,010$ & \\
\hline \multirow{2}{*}{ Arsenic [mgAs/l] } & $<0,020$ & $<0,020$ & $<0,020$ & $<0,020$ & $<0,020$ & \multirow{2}{*}{0,1} \\
\hline & $<0,020$ & $<0,020$ & $<0,020$ & $<0,020$ & $<0,020$ & \\
\hline \multirow{2}{*}{ Nickel [mgNi/l] } & $<0,010$ & $<0,010$ & $<0,010$ & $<0,010$ & $<0,010$ & \multirow{2}{*}{0,5} \\
\hline & $<0,010$ & $<0,010$ & $<0,010$ & $<0,010$ & $<0,010$ & \\
\hline \multirow{2}{*}{ Petroleum compounds [mg/l] } & $<0,10$ & 0,27 & $<0,10$ & 0,18 & 0,13 & \multirow{2}{*}{15,0} \\
\hline & No data & 0,14 & $<0,10$ & $<0,10$ & $<0,10$ & \\
\hline Suspension [mg/l] & 23 & 20,4 & 24,8 & 6 & 8 & 35 \\
\hline
\end{tabular}

Source: CTL Maczki-Bór S.A..

\section{CONCLUSIONS}

Due to the poor water resources of the country and the poor quality of water in Poland, it is necessary to systematically strive to improve the condition of rivers in Poland. The degree of salinity of flowing waters in Poland presented in the article, illustrates the large scale of the problem that is the over-normative salinity of Polish rivers. The impact resulting from the discharging of salt water from hard coal mines to rivers in this region, causes contamination of other parts of the country, caused by a large amount of chloride and sulfate discharges along with the Vistula and Odra rivers. The high salinity of the Odra waters, which is the border between Poland and Germany, causes that the problem of over-normative salinity of waters flowing in Poland takes on an international character. Knowledge of the degree of water salinity is therefore very important for political, ecological and economic reasons. Bad water quality makes it impossible to use them for industrial, economic or recreational purposes. Determining the sources of water salinity is important due to the indication of appropriate remedies that can partially or completely eliminate the negative impact of saline waters on the aquatic environment. This is particularly important in the case of underground water discharging from hard coal mines, which are the main source of river salinity. Considering the large amount of salt water discharged by mines, for technical and economic reasons it is not possible to completely eliminate this problem, however, it is possible to partially avoid this problem by applying appropriate methods of management and utilization of these waters. In line with EU requirements, Polish mines are gradually implementing environmental protection 
systems. When planning a new investment, they use and implement possible environmental technologies, contributing to reducing the amount of pollutants introduced into the environment. In addition, the introduction of appropriate remedial actions related to water protection in many industrial plants, which, in addition to the mine, also have an impact on the salinity of water, may contribute to reducing the degree of water salinity in Poland. The example of water discharged from the excavation filled with mining waste given in the article indicates a low degree of deterioration of surface.

The most important aspect of depositing mine waste is minimizing the negative impact on the natural environment. One of the basic directives in force in the field of environmental protection is the precautionary principle that obliges entities that may have a negative impact on the environment to prevent the emergence of such impacts. In practice, it is not always possible to implement it, therefore, in the current system of environmental protection introduced a whole range of legal instruments intended to bring the environment to the proper state in case of negative changes in it.

Reclamation of excavations with mining waste causes impact on surface waters, bringing in sulphates, chlorides, iron and manganese, but generally water pumped from the Mielnik Maczki-Bór Mining Plant and discharged through the sandstone to the Biała Przemsza River in the light of the ordinance of the Minister of Environment of 7 November 2019 on the method of classification of the surface water bodies and environmental quality standards for priority substances slightly affect the quality of water in the Biała Przemsza River, allowing it, in the case of the majority of analyzed parameters, to preserve the chemical status of water as before their introduction to river.

In the event of an imminent threat, there is an obligation to immediately take preventive measures, including immediate control, containment, removal or reduction of pollution or other harmful factors e.g. by controlling leachate effluent flows.

\section{ACKNOWLEDGEMENTS}

The results of the research come from the internal data of the company CTL Maczki-Bór S. A., carried out in accordance with the decisions of the Marshal of the Silesian Voivodeship and Polish legislation. For the purposes of the article, the results of the research were compiled and gave rise to the conclusions.

\section{BIBLIOGRAPHY}

Chełmicki W., 2002. Water. Resources, Degradation, Protection (Woda. Zasoby, Degradacja, Ochrona), Warszawa: Wydawnictwo Naukowe PWN (in Polish).

Environmental monitoring in the area of the "Bór-Zachód" and "Bór-Wschód" grit chamber CTL "Maczki Bór” 2012 (Monitoring środowiska w rejonie wyrobiska piasku „Bór-Zachód” i „, Bór-Wschód” CTL ,Maczki Bór”) (in Polish).

Environmental monitoring in the area of the "Bór-Zachód" and "Bór-Wschód" grit chamber CTL "Maczki Bór” 2013 (Monitoring środowiska w rejonie wyrobiska piasku „,Bór-Zachód” i „Bór-Wschód” CTL ,Maczki Bór”) (in Polish).

Environmental monitoring in the area of the "Bór-Zachód" and "Bór-Wschód" grit chamber CTL "Maczki Bór” 2014 (Monitoring środowiska w rejonie wyrobiska piasku „Bór-Zachód” i „, Bór-Wschód” CTL ,Maczki Bór”) (in Polish).

Environmental monitoring in the area of the "Bór-Zachód" and "Bór-Wschód" grit chamber CTL “Maczki Bór” 2015 (Monitoring środowiska w rejonie wyrobiska piasku „Bór-Zachód” i „, Bór-Wschód” CTL ,Maczki Bór”) (in Polish).

Environmental monitoring in the area of the "Bór-Zachód" and "Bór-Wschód" grit chamber CTL "Maczki Bór” 2016 (Monitoring środowiska w rejonie wyrobiska piasku „Bór-Zachód” i „, Bór-Wschód” CTL ,Maczki Bór”) (in Polish).

Główny Urząd Statystyczny, 2018. Environment 2017 (Ochrona środowiska 2017). online: http://stat.gov. pl/files/gfx/portalinformacyjny/pl/defaultaktualnosci/5484/1/18/1/ochrona_srodowiska_2017.pdf [access 15.11.2018]. 
Grynkiewicz-Bylina B., Majewski M., 2000. Monitoring of mine waters salinity (Monitoring zasolenia wód kopalnianych), KARBO No. 2, pp. 60-65 (in Polish).

Inspekcja Ochrony Środowiska Wojewódzki Inspektorat Ochrony Środowiska w Katowicach, 2018. State of the environment in Ślaskie Voivodeship in 2017 (Stan środowiska w województwie ślaskim w 2017 roku), Katowice: Biblioteka Monitoringu Środowiska (in Polish).

Kugiel M., Piekło R., 2012. Directions of mining waste management in Haldex S. A., (Kierunki zagospodarowania odpadów wydobywczych w Haldex S. A.), Górnictwo i Geologia, T. 7 z. 1, pp. 133-145.

Lipiński K., 1987. Protection of wateragainstsalinity (Ochrona wód przed zasoleniem), Ochrona Środowiska, $\mathrm{Nr}$ 521/1(31), pp. 7-11 (in Polish).

Miller P., 2004. Salinity of waters in Poland (Zasolenie wód w Polsce), Przyroda Polska, No. 10, pp. 24-25 (in Polish).

Nocoń K., Nocoń W., 2011. Flowing surface water of the Silesian agglomeration - problems and challenges (Plynace wody powierzchniowe aglomeracji ślaskiej - problemy I wyzwania), Ochrona Środowiska, No. 3, pp. 26-31 (in Polish).

Państwowy Instytut Geologiczny, 2018. Balance of mineral resources in Poland at 31.12.2017 (Bilans zasobów złóż kopalin w Polsce wedlug stanu na dzień 31.12.2017), online: https://www.lw.com.pl/pl,2,d1097, gospodarka_odpadami.html [access: 15.11.2018]. 